University at Buffalo School of Law

Digital Commons @ University at Buffalo School of Law

1993

\title{
Origin Myths: Narratives of Authority, Resistance, Disability, and Law
}

David M. Engel

University at Buffalo School of Law

Follow this and additional works at: https://digitalcommons.law.buffalo.edu/journal_articles

Part of the Law and Society Commons

\section{Recommended Citation}

David M. Engel, Origin Myths: Narratives of Authority, Resistance, Disability, and Law, 27 Law \& Soc'y Rev. 785 (1993).

Available at: https://digitalcommons.law.buffalo.edu/journal_articles/466

(C) 1993 Law and Society Association

\section{IN COPYRIGHT}

This Article is brought to you for free and open access by the Faculty Scholarship at Digital Commons @ University at Buffalo School of Law. It has been accepted for inclusion in Journal Articles by an authorized administrator of Digital Commons @ University at Buffalo School of Law. For more information, please contact lawscholar@buffalo.edu. 
Origin Myths:

Narratives of Authority, Resistance, Disability, and Law

\title{
David M. Engel
}

\begin{abstract}
Origin stories are a distinctive form of narrative. In their account of how something "began to be," such stories connect past and present, clarify the meanings of important events, reaffirm core norms and values, and assert particular understandings of social order and individual identity. The parents of children with disabilities tell strikingly similar origin stories about the day their child was first diagnosed. Such stories not only explore the meanings of a transformative event but also draw implicit connections between past encounters with medical specialists and present encounters with educational specialists as mandated by an important federal statute. This article, based on an ethnographic study of parents, children, and educators, traces the implicit references in the parents" origin myths to a set of key oppositions that reflect their experiences within the statutory framework of special education: cooperative versus unilateral decisionmaking, lay versus professional knowledge, and authority versus legal empowerment. The article also compares the ways in which law and myth address the conflicting perspectives of disability specialists and of the parents and children themselves.
\end{abstract}

\section{I. "It Was a Tough Day"}

What I have written here strains to be true but nevertheless is not true enough. Truth is anecdotes, narrative, the snug opaque quotidian.

-John Updike, Self-Consciousness: Memoirs (1989:246)

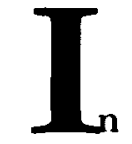

everyday conversation, the talk of parents of children with disabilities circles back from schools, vacation trips, friends, and neighbors to earlier experiences with educators, psychologists, doctors, and lawyers. One story parents often tell each other concerns the first such encounter, the moment

For their helpful comments at various stages in the writing of this article, I would like to thank James Atleson, Don Brenneis, Paul Hyams, Fred Konefsky, Frank Reynolds, Jack Schlegel, Richard Sherwin, Avi Soifer, James Boyd White, and Lucie White. The research for this study was made possible by grants from the Law and Social Sciences Program of the National Science Foundation (Grant SES 87-0330), the American Council of Learned Societies, and the Baldy Center for Law and Social Policy. Address correspondence to David M. Engel, School of Law, State University of New York at Buffalo, Buffalo, NY 14260. 
they first learned that their child was "handicapped," the day on which their lives veered suddenly down an unexpected path. Parents tell these "origin" stories with heightened feeling: the stories are laden with special meaning. And, despite enormous differences among families and children, the stories are remarkably similar. ${ }^{1}$ Consider, for example, the story told by Christine and Robert Campo during a conversation with the author (who is also the parent of a child with a disability): ${ }^{2}$

1 This article draws on an ethnographic study of children with disabilities, their families, and the public school systems with which they dealt. The study was based primarily on lengthy, loosely structured interviews, which were tape-recorded and transcribed. All quotations in this article are taken verbatim from these transcriptions.

There were about 140 interviews with parents, some of which involved the participation of the children themselves. The interviews were conducted in urban, suburban, and rural settings in Western New York over a 15-month period in 1987 and 1988.

Participants for the parent interviews were selected in two ways. One group (38 families) was contacted through the United Cerebral Palsy Association (UCPA). These were families whose children had attended the UCPA preschool program and later fell under the jurisdiction of their school district's Committee on Special Education (see discussion of the CSE infra). Of these families 10 were selected for frequent interviews throughout the research period; 20 were interviewed at the beginning and end of the study; and 8 were interviewed only once, because their children had just reached school age at the end of the research period. A second group (19 families) was contacted through the Education Law Clinic of the School of Law, State University of New York at Buffalo. The children in this group also had physical disabilities but had not necessarily attended the UCPA preschool program. They were selected so that we could obtain the insights of parents who had made the decision to seek legal assistance in their dealings with the school system.

In addition to the parent interviews, 30 interviews were conducted with chairpersons and other members of school district Committees on Special Education in 18 school districts throughout Western New York. In a related study conducted by Susan Weber, who was then my research assistant, every committee member in two selected school districts was interviewed.

Because of the sensitive nature of these interviews, parents and educators were promised anonymity. Names of parents and children in the article are pseudonyms. All transcripts are on file with the author.

2 Recent literature on ethnography and cultural interpretation has critically examined the relationship between researcher and subject and the processes by which researchers attempt to represent the words, experiences, and perspectives of those they study (see, e.g., Marcus \& Fischer 1986; Clifford 1988a). Being aware of these concerns, I should make it clear at the outset that, in one sense, I am a member of the group among which I did my research: I am the parent of a child with a physical disability, and my child attended the same UCPA preschool as did most of the children in this study (although only a few of the children and parents in the study were known to me before I began my research). I participated in conversations and listened to the storytelling of fellow parents for years prior to my formal research. Many of the experiences with educators and disability specialists that are described in this article resonated with my family's experiences. Moreover, participants in this study often told me during interviews that they felt able to speak openly and frankly to me because I was a fellow parent, and they thought I would fairly communicate their perspective in my writing.

Nonetheless, this is not a confessional or autobiographical essay. Neither my fam. ily's experiences nor any aspect of our own school district have been brought into this discussion. The "origin stories" told by many parents were not a part of our family's experience: we were fortunate that the initial diagnosis of our child's disability was presented to us with great sensitivity and compassion by an exceptional team of specialists in Evanston, Illinois.

The origin stories that are the subject of this essay are not, therefore, a narrative form that I myself have ever used. What I have shared with the diverse group of individuals and families who appear in the pages that follow is the experience of raising a child with a disability in a particular culture and geographical area at a particular histor- 
Christine Campo: I hate him [the neurologist]. And you can publish that. The man was so cruel when we went to get the final diagnosis. He was so cruel. He gave it to us like, oh, it was terrible. One of the worst moments of my life. I could barely walk out of the building.

Author: Do you mean he was blunt or he exaggerated how bad it was?

Christine Campo: Blunt, and he exaggerated and was cruel. I mean it was just like, boom, boom, boom. And he had a resident with him sitting there and observing, and I think he performs for people. ... And he said, "What have you been told about your son?" And I said, "Well, Dr. Seager suspected he might have CP." And you know, you're always hoping they're wrong.

Robert Campo: I never understood exactly what CP was anyways in the first place. And then to have this guy just throw it at you like that, it was really, it was kind of brutal.

Christine Campo: Oh, it was so cruel. He said, "Well, he's right. And he may be mentally retarded, he may be an invalid, he may end up in bed all of his life."

Robert Campo: "He'll never walk," and that.

Christine Campo: And it was just boom, boom, boom. And it was like somebody shooting you or something.

Robert Campo: It was a tough day.

Christine Campo: And you get up and he shoots you again. And I'd like to say right now that Ben [their son, now a teenager] is on the honor roll. He is always being featured on TV for the telethon. He's a celebrity child. They've had him in the newspaper on the front page doing articles on him.

I heard stories of this kind so often-and they were told with such emotion-that they demanded attention and interpretation. At first I thought they were simply about doctors who lack sensitivity in communicating with patients or, perhaps, that the parents were blaming the messenger for a particularly distressing message. In time, however, I came to understand that there are other meanings embedded in these remarkably similar stories and that they refer to the present as much as to the past. When Christine Campo refers to current achievements by her son Ben, she provides a clue as to the present concerns that animate these narratives of the past. There are other clues, I shall suggest, that point toward an even broader reference to-and critique of - the narrator's circumstances at the time of narration. These circumstances include a range of social and legal concerns that go far beyond the troubling encounter with the doctor that is the ostensible subject of the narratives.

ical moment. My narrative response to this experience, at least for now, takes the form of an essay that attempts to communicate and to understand the voices of the parents and professionals whose interactions are so critically important for these children. 
In the discussion that follows, I suggest that stories of this kind constitute a form of "myth-making" in everyday life and that such myths are highly relevant to the practices and perceptions of parents as they negotiate their way through the educational and legal systems on behalf of their children. Myth-making, in this view, is part of the process of constructing a world in which the families and children can live. This process is not a unilateral act but involves interactions and occasional conflicts with others-educators, psychologists, social workers, therapists, doctors, and lawyers-who may hold different views. As much as anything else, the myths reflect and weave meanings around such interactions.

This essay begins with a presentation of the myths themselves, but it then follows their implicit references to a set of circumstances that exist at the time the myths are told. Years have passed since the day the child was first diagnosed. The child is now in school; the parents find themselves enmeshed in the complex structure of special education that seems simultaneously to demand their participation and to reject their views and preferences. The special education system is pervaded by the professional culture and practices that have developed around the concept of disability in our society, but the system is also fundamentally a creature of the law. The experiences of parents and their school-age children are the consequence of a sweeping federal civil rights act designed to integrate children with disabilities into the educational mainstream.

As it tracks the sometimes difficult relationships between parents and professionals from the day of diagnosis to the later processes of educational planning, this essay focuses on law as well as myth. Law has structured the encounters with professionals that parents describe as frustrating and intimidating. Law also offers the parents a set of rights that could redress the imbalance of power and give greater weight to their views and wishes. Yet parents generally reject the law as a solution to their problem. They fear (and their apprehensions are echoed by many educators' hostility toward lawyers and legal procedures) that recourse to the law will ultimately embed them even more deeply in the adversarial and oppositional relationships whose effects they find so painful.

The origin myths express the parents' awareness that they live in a divided world marked by conflict and disparate understandings of their child. The myths point to the source of these divisions: professional and lay responses to the fact that the parents have given birth to a child society views as deviating from the "norm" in certain culturally important ways. The origin myths also express an aspiration-and a determination-to transcend the situation in which the parents and children find themselves and to restore a sense of unity to their everyday 
lives. Paradoxically, the parents of children with disabilities discover that law works both to realize and to frustrate the creative force of myth.

\section{Myth and Meaning}

In the frame of such an existence, what could suffering and pain signify? Certainly not a meaningless experience that man can only "tolerate" insofar as it is inevitable, as, for example, he tolerates the rigors of climate. Whatever its nature and whatever its apparent cause, his suffering had a meaning; it corresponded, if not always to a prototype, at least to an order whose value was not contested.

-Mircea Eliade, Cosmos and History: The Myth of the Eternal Return ([1949] 1959:96)

What is the significance of stories that are often retold? What distinguishes everyday stories from those that take on the attributes of myth?

The narrative act is so fundamental to human society that it is hard to imagine what life would be like without the telling of stories. Isaac Bashevis Singer (1976:10-11) was not the first to observe that, in a sense, human life is storytelling:

When a day passes, it is no longer there. What remains of it? Nothing more than a story. If stories weren't told or books weren't written, man would live like the beasts, only for the day. ... Today we live, but by tomorrow today will be a story. The whole world, all human life, is one long story. ${ }^{3}$

In Acts of Meaning, Jerome Bruner (1990:111) describes the recognition among some psychologists in the 1970s and 1980s that the Self is defined through the stories people tell and that the "narrative truth" rather than the "historical truth" is what matters most about these stories for the construction of identity. This insight was later broadened, by Bruner (pp. 116-17) and others, to a recognition that the negotiation of the Self is not an isolated process but involves the society and culture within which the individual lives and acts.

The role of narrative in constructing concepts of self and society has become clear in a multitude of studies, including those addressing a broad range of law-related issues such as race (e.g., Bell 1987; Davis 1989; Delgado 1989; Williams 1989), gender,4 community (e.g., Engel 1984; Greenhouse

3 "Naftali the Storyteller and His Horse, Sus" (Singer 1976) is a children's story; the speaker is Reb Zebulun. I encountered this passage in a newsletter for parents of individuals with disabilities (PACER Center 1991-92:1)

4 A pioneering example of the use of narrative to address issues of law and gender is found in the work of Susan Estrich (1986). Her work and that of other feminist narrative scholars are skillfully summarized, discussed, and defended by Kathryn Abrams (1991) (focusing in particular detail on the work of Martha Mahoney, Patricia Williams, and Marie Ashe). 
1986; Clifford 1988b; Perin 1988; Yngvesson 1988; Merry 1990; Greenhouse et al. forthcoming 1994), and the practice of law (e.g., Sarat \& Felstiner 1988; Cunningham 1989; Conley \& O'Barr 1990). Studies of law and literature have also emphasized that storytelling can construct a world in which values, identities, norms, and relationships are defined through the selectivity and creativity of the narrator (e.g., White 1984, 1985; Sherwin 1988). As James Boyd White (1990: ix) has observed, "our acts of language are actions in the world, not just in our minds. . . . Whenever we talk we create a character for ourselves and a relation with others: we offer to constitute a community of a certain kind, for good or ill, and this is often the most important part of what we do."

The subject of this essay is a particular kind of narrative, a kind I identify as "myth." I will suggest, to borrow White's phrase, that the act of telling myth-like stories "creates a character" for children with disabilities and their parents as well as defining a relationship to others. I will explore the ways in which such narratives situate the parents and children in relation to the professionals with whom they must continually interact and in relation to the law which they may or may not choose to invoke.

Why term these stories "myths"? It is useful to recall some of the characteristics that have been associated with myth. According to Eliade (1963), who remains one of the most influential writers on the subject, myth in "archaic" societies refers not to fantasy or fiction but to a "true story": "and, beyond that, a story that is a most precious possession because it is sacred, exemplary, significant" (p. 1). Myth provides "models for human behavior and, by that very fact, gives meaning and value to life" (p. 2). Myth, therefore, simultaneously announces meaning and shapes behavior, it looks backward and forward, it explains and it constrains.

The "truth" of myth differs from the "truth" of historical or scientific accounts. Eliade ([1949] 1959:44-46) tells of a mythlike ballad recorded in a Rumanian village by the folklorist Constantin Brailoiu. According to the myth, a jealous mountain fairy had bewitched a young man and flung him from a cliff shortly before he was to be married. His fiancee, in the company of a group of shepherds who recovered his body, sang a beautiful lament "full of mythological allusions." As it happened, Brailoiu discovered that this myth referred to events that were quite recent in origin and that the fiancee was still alive. By interviewing her, he was able to discover some signifcant discrepancies between the mythic account and her own recollections of the same events. She explained that the young man had in fact slipped and fallen over the cliff; that he was still alive and in pain when the shepherds brought him back to the 
village; that when he eventually died from his injuries, the fiancee did not sing a distinctive funeral lament; and that no one at the time explained his death in terms of a jealous mountain fairy. What is significant about this rapid transformation of an ordinary misfortune into myth is that the villagers rejected the fiancee's "true" historical reconstruction of the event, even though many of them were also present at the time of the young man's death. For them, the myth spoke to a deeper reality-it was truer than truth: "When the folklorist drew the villagers' attention to the authentic version, they replied that the old woman [i.e., the fiancee] had forgotten; that her great grief had almost destroyed her mind. It was the myth that told the truth: the real story was already only a falsification" (p. 46).

Myth, then, differs from history in its quest for deeper meanings and for archetypes rather than for objective certainty. It starts with the materials of human experience but transforms their particularities into narratives that speak more broadly about the essential nature of self and society. ${ }^{5}$ As Austin (1990:2) has suggested, "The student of myth must, sooner or later, become a cosmologist since every myth both presupposes and illustrates a cosmology, as every fact presupposes a complete theoretical system."

Myths, and the cosmologies they encode, often reflect the dominant ideological systems in a society, but myths can also be constructed by subordinate or disempowered groups. As current jargon would have it, myths can also be counterhegemonic statements or instruments of struggle against the established order (compare Lincoln 1989:7). Indeed, I suggest in this essay that the myths constructed by parents of children with disabilities emerge from troubled interactions between the parents and the established order and constitute a critical commentary by the parents on those interactions.

There is another characteristic of myths that distinguishes them most significantly from other forms of storytelling: They tend to deal with origins, with birth, with beginnings. Eliade (1963:5-6) noted this emphasis in the myths of "archaic" peoples, which were typically stories of gods and goddesses:

$[\mathrm{M}]$ yth tells how, through the deeds of Supernatural Beings, a reality came into existence, be it the whole of reality, the Cosmos, or only a fragment of reality-an island, a species of plant, a particular kind of human behavior, an institution. Myth, then, is always an account of a "creation"; it relates how something was produced, began to be. (Emphasis in original)

The myths of everyday life in contemporary society, unlike

5 " $[M] y t h$, though determined in its form by its immediate historical context, transcends any historical moment, being at the fundamental level the quest for the self' (Austin 1990:2). 
those of "archaic" peoples, do not necessarily deal with supernatural beings, but the emphasis on "how something ... began to $b e$ " remains an essential attribute, one that is readily apparent in the stories told by parents about the initial diagnosis of their child's disability.

The retelling of myths about origins represents, in Eliade's view, an attempt to transcend historical time, with its relentless linear progression, its "irreversibility." Myths reaffirm the cyclical nature of time, the capacity of humans to return to "beginnings" and to "regenerate themselves periodically by abolishing past time and reactualizing the cosmogony" (Eliade [1949] 1959:74). The return to primal events allows humans to clarify existential meanings that are sometimes obscured by the misfortunes and suffering that drain everyday life of its value and direction. By transcending linear, "historical" time, the narrators of myths not only regenerate themselves but also reaffirm and "reactualize" the cosmic order that they find encoded in the myths. The retelling of myths allows the narrators to rework the raw materials of experience according to shapes and patterns that now appear significant and to explore their implications for contemporary situations. Myths-like dreams-allow the narrators of past events to "keep doing it until they get it right," to wrestle with an account of what occurred and what was said until fundamental truths shine through the story. These truths illuminate not only the past but the time of the retelling. The retelling of myths is thus many things at once: an act of insight, a reinterpretation of the past, a reaffirmation of core values and beliefs, and a "reactualization" of the cosmic order.

\section{Diagnosis}

There is something curious about autobiography. It is an account given by a narrator in the here and now about a protagonist bearing his name who existed in the there and then, the story terminating in the present when the protagonist fuses with the narrator. . . The Self as narrator not only recounts but justifies. And the Self as protagonist is always, as it were, pointing to the future.

-Jerome Bruner, Acts of Meaning (1990:121)

The story told by the Campos, quoted above, recounts a chilling moment when existence seemed frozen and suspended between conventional expectations for their family and a future of suffering and uncertainty. They analogize that moment to an attack by a sadistic gunman who shot them again and again as they attempted to regain their feet. Playing to his audience (a young resident), the doctor dramatized the bad news, expressing no sympathy or sensitivity and presenting the diagnosis in 
the most negative terms possible. The prognosis was very bad: their son could be permanently bedridden and "retarded;" he would make little progress and give them no parental satisfaction. At the end of their story, the Campos stress how wrong the doctor was. Their child had become a teenager who was mobile enough to attend high school, intelligent enough to be an honors student, and successful enough to bring satisfaction to his family and to others who read about him in the newspaper or saw him on the television.

The stories parents tell about the diagnosis of their children's disabilities are of two basic kinds. One group of stories resembles that of the Campos in most significant respects. The doctor was cruel and insensitive; the diagnosis was overly negative; despite the doctor's dire predictions, the child has gone on to achieve far more than anyone thought possible. Carla Weiss, for example, recalls that her doctor told her that her 11 month-old child "was going to be a vegetable" and should be institutionalized. "They felt that he wasn't going to progress into anything. The best idea was to put him in a home and forget about him." She ignored the neurologist's advice and, as her child grew older, he eventually entered the public school system, got around with a wheelchair and a walker, and became an avid sports fan. Nancy Moore recalls the words of her child's neurologist (by chance, the same doctor who diagnosed the Campos's child):

"There is no hope for [your child]." He said, "Just as you see her there right now"-this is when she was two months old!- " this is how it's always going to be. She is never going to walk, talk, crawl. She's never going to be nothing more than a vegetable." He sees her now, and I can't help but smile. And Dr. Wood doesn't smile.

In one of the most disturbing variations on this theme, Christine Hibbard remembers that when her daughter was one year old, her doctor told her that the child should be sterilized. Exaggerated or erroneous initial diagnoses can thus have lasting effects, although parents take pleasure in telling how their children have ultimately prevailed. Mary Perkins, for example, was told that her 9-month-old child was severely mentally retarded as well as physically disabled. This diagnosis, although incorrect, stayed with her child for the next nine years. Every sign of intelligence was dismissed by his teachers: "Oh, he's just very verbal. He's very verbal, that's all. It's a mask. He's really retarded. He's just very verbal-look at his mother!' It was not until the boy was 10 years old, having been educated with other "retarded" children all his life, that the error in the diagnosis was finally recognized by someone other than his mother. 
In telling their story of the initial diagnosis, parents ${ }^{6}$ often draw on a second narrative pattern that, at least superficially, seems to contradict the first. In this second type of story, it is the parents who first realize that something is "wrong" with their baby, but, try as they might to persuade the doctor, their apprehensions are discounted and the evidence of their own perceptions is ignored. The following story is told by Elaine Brown, whose husband as well as her pediatrician refused to accept her assertions that the child was not developing "normally:"

He wasn't tracking. I mean, I was watching him, and he wasn't tracking. And Dr. Williams is telling me, "Oh, I don't think ..." I said, "Well, what about sitting? I know it's still a little too early for him to sit, but there's NOTHING. I mean, there's absolutely nothing there. You know, he's not grasping anything. He's not even batting anything yet. There's nothing." "Well, give him time. If you don't have problems, blah, blah, blah."

Well, by this time I was really starting to get panicky. And this was still all behind my husband's back. . . I would say something very meekly, like, "Oh, did you notice, Eric doesn't look at the boys when they walk by. . . . And by now my husband was starting to get irritated. ... .

And another thing was his one eye was, like, turned in, like right toward his nose? And it would just flop back and forth. And that's, my kids saw that. And when I took him to Dr. Williams, I said, "What about his eye?" "Well, it's just a lazy eye, and when he gets older if it doesn't go away, we can put a patch on it. ..."

I think he was afraid. I think he was, he knew but he didn't want to be the one to tell me... .

Eventually she persuaded her doctor to refer them to a specialist, and she insisted that her husband take the day off from work in order to accompany her to the specialist's office. Elaine Brown's story continues:

Dr. Kennedy came in and he worked, you know, stretching his legs and his arms and turning his head, and he looked at his eyes and the whole business. And he said, "I am making a diagnosis of cerebral palsy here." . . . He said, "He needs extensive therapy." And he said, "I cannot tell you if he will ever walk or talk or be a normal child." .. Well, my husband, he turned white as a sheet. I thought he was going to faint

6 It may already be apparent that most-but not all-of the parents quoted in this article are mothers rather than fathers. In considering the power disparities between parents and professionals, it is important to keep in mind that the parent most often involved on behalf of the child is the mother. Gender stereotypes undoubtedly play a part in the construction of authority and in assumptions about objectivity and subjectivity in the decisionmaking process. Nevertheless, it would be an oversimplification to refer only to "mothers" rather than to "parents" in this discussion. Fathers often participated in my interviews, though they were often less vocal than their spouses, and their views and their role in the CSE process cannot be overlooked. 
right there in the room. I started to cry, I don't know why, but I just started to cry. I mean, I knew, but I just started to cry, and he's looking at me, and then he started to cry.

In this second type of story, told with the same degree of intensity as the first, the diagnosis of disability does not come as a surprise to the parent (at least not to the mother in this story). Indeed, the parent is well aware that things are "not right" with the child but cannot convince the doctor to pay attention to her concerns. Typically, the parent in question is the mother; and sometimes, as was the case with Elaine Brown, her husband joins the doctor in denying the importance of the signs or symptoms she reports.

Elaine Brown now suspects that her pediatrician knew Eric had cerebral palsy but was too timid (or perhaps soft-hearted) to acknowledge what was already obvious even to Eric's siblings. Parents who tell stories similar to Elaine Brown's, however, do not usually interpret the doctor's "denial" in a positive light. In Mary Roth's account, for example, her doctor was not protecting her but ignoring her:

For a year this idiot pediatrician said, "He'll walk when he's ready, he'll talk when he's ready, he'll do this when he's ready." And I kept crying to my parents, "This isn't right." But what else do I do? They said, "Find another doctor." I said, "But this is who all my friends go to." You know, what could be wrong with a pediatrician? He's a trained man. Well, little did I know.

Mary Roth found it frustrating that the doctor condescendingly interpreted her concerns as the imaginings of an overanxious mother. When she moved to another city, she saw a new doctor, who immediately made the diagnosis of cerebral palsy. By then, her child was already 15 months old.

Parents, especially mothers, recall with anger that their doctors told them they were imagining things. Cynthia Miller's story suggests that she knew there was something wrong "as soon as I held him after he was born. I didn't think he was as strong. He was very floppy." Could a disability actually be detected that soon after birth? Clearly her doctor did not think so: "He kept telling me that I was looking for problems." Ultimately, her suspicions proved to have been justified. Rachel Dolan, who told her pediatrician that her son seemed listless and unresponsive, was reassured that he "was a lazy baby. Don't worry about it." Cynthia Mueller recalled that her son's pediatrician ignored her concerns for a year and a half:

Then, at 18 months old, I finally got fed up with it because he wasn't walking yet or anything. And I told the doctor, "Listen, I'm coming in. I think he's not walking right." And when I went in there, he says, "By golly, you're right. He's not." He said, "Take him to a neurologist." So we did. 
In each of these stories, conflict between parent and doctor arises because the doctor refuses to acknowledge "facts" that the parent can see with her own eyes. The doctor dismisses the parent's concerns on the grounds that all parents-especially mothers, whose gender is seen to make them vulnerable to emotionalism and subjectivity-tend to be overly anxious about their own children and to imagine that there are problems when none in fact exist. In each of the stories, the doctor is ultimately proved wrong and is forced to accept the validity of the parent's concerns. In telling the stories, the parent emphasizes not only her own vindication but the harm resulting from the doctor's refusal to listen: harm to the child (who could have started therapy or treatment earlier), to the family (marital problems in the Brown family were exacerbated by the doctor's rejection of Elaine's concerns about their baby), and to the mother (whose self-esteem was injured when professionals treated her as an irrational person incapable of forming mature judgments about the well-being of her own child).

Stories of this second type contrast in some ways with stories of the first type. In the second group of stories, it is the parent rather than the doctor who first recognizes that the child has a disability. The doctor is not overly blunt about the child's condition. Rather, he or she seems oblivious to serious indications that there is a problem requiring attention. The parent is not naive or blissfully ignorant but on the contrary is convinced long before anyone else that her child is not developing or behaving normally.

Despite these superficial differences, the two types of stories are essentially similar. In both instances, there is a fundamental opposition between parent and doctor, a clash of perspectives and of personalities. In both instances, the doctor violates basic norms of decency and respect by dealing with the parent in a way that disregards her dignity as a person. In both instances, it is the parent rather than the doctor who behaves "normally" and the doctor whose behavior is inexplicable and beyond the bounds of normal civility. In both instances, the doctor relies on esoteric, scientific knowledge but is wrong about the child, while the parent relies on ordinary common sense and is right.

Because these "origin" stories teach such basic lessons and rely on such fundamental, archetypal images of parent and doctor, they function as myths of everyday life. If one were to attempt to reconstruct the history of these early encounters in the doctor's office by drawing on other sources and perspectives, one might find that the doctors remember the events quite differently from the parents. The purpose of this discussion, however, is neither to.assert nor to question the historical accuracy of the parents' narratives but to ask what deeper 
"truths" the parents convey in telling them, why the parents tell them so often, and why the same basic narrative patterns emerge again and again.

As myths, these stories deal with "beginnings," with "how something. . . began to be" (Eliade 1963:5-6). The encounter in the doctor's office represents the moment of transformation, the moment when the child's disability was officially registered as a fact that would change the family's life forever. ${ }^{7}$ In retelling the story of this "beginning," the parent "illustrates a cosmology" (Austin 1990:2) by showing how the interaction between professional and layperson is fundamentally oppositional, how the layperson suffers from but ultimately triumphs over the professional in this unequal relationship, how common sense proves superior to science, and how the child transcends the analytic categories of the very experts who are there ostensibly to assist the child. The recapitulation of this "cosmology" is very important to the parents, not only in giving meaning to past events but in clarifying their circumstances at the time the stories are retold. In this sense, as Bruner (1990:121) observes of autobiographical narratives in general, they speak not only to the past but to the present and future.

As is generally the case with myths, the element of time is central: both "the time of the stories and the time in the stories" (to paraphrase Gertrude Stein). ${ }^{8}$ Retelling the stories is a way to triumph over the particularities of historical time, to escape the pain and frustration of day-to-day events and to affirm instead the lasting truths embedded in the mythical accounts of these first encounters between parents and professionals.

I have suggested why these narratives might be considered myths of everyday life and what values and worldviews they encode. In the discussion that follows, I try to explain why the stories have such significance for parents of children with disabilities. Specifically, I examine three themes that link these narratives of the past to the parents' present concerns with schools and the special education system for children with disabilities. The first theme is that of parental exclusion from the processes of evaluation and decisionmaking affecting their child. The second theme concerns clashes in the ways in which parents and professionals perceive children with disabilities. The third theme involves power disparities between parents and professionals in dealings concerning the children. All three themes

7 This moment of professional classification has enormous personal significance for the families, but it also has legal, medical, and financial implications: Once a diagnosis is made, a range of professional services and entitlements becomes available, insurance reimbursements are provided, educational placements and programming are initiated, and so on. I will discuss some of these sequelae below.

8 "It is understood by this time that everything is the same except composition and time, composition and the time of the composition and the time in the composition" (Stein 1926:12). 
resonate in both the origin myths and in parents' stories about current schools, teachers, administrators, and disability specialists. ${ }^{9}$

In discussing each of these three themes in turn, I suggest linkages between origin myths and narratives of everyday life in the present. Indeed, I argue that the origin stories are not fully understandable unless the later, school-related narratives are taken into account. As we have seen, the telling of myths is in some senses an attempt to transcend time. It is, therefore, essential to consider how the meanings and significance of the origin stories are established through connections across time and to stress the relevance of these myths to the world of the narrator at the time the myths are retold.

\section{Participating in Decisions about the Child}

The historians have demonstrated that there is no such thing as an even theoretically impartial observer, and the anthropologists have cynically undermined our hopes of getting inside the heads of other cultures, relativistically or otherwise. The linguists and philosophers have, finally, hopelessly defamed the character of language as a possible vehicle for mutual understanding. So we are stripped down to our naked myths, the bare bones of human experience. They may be our last hope for a nonlanguage that can free us from these cognitive snares, a means of flying so low that we can scuttle underneath the devastating radar of the physical and social sciences and skim close to the ground of the human heart.

-Wendy Doniger O'Flaherty, Other Peoples' Myths:

The Cave of Echoes (1988:166)

At least once a year, usually in the spring or early summer, parents of each child with disabilities meet with a Committee on Special Education (CSE) ${ }^{10}$ in their school district to draw up

9 One additional point should be emphasized. The focus of the discussion will shift from past to present, but the topic of discussion remains the same: the stories parents tell about their experiences and those of their children. Although it would be interesting to know how other actors in these particular stories viewed the same events-and what narratives they might tell about them-in most instances it would have been impossible to gain access to the perceptions of such actors (e.g., teachers, administrators, psychologists) without violating assurances of confidentiality given to the parents and, in some cases, placing both children and parents at risk. A number of educators and other professionals were interviewed for this study, but their viewpoints are presented here in general terms and not in response to the details of specific cases or stories described by the parents. Their viewpoints are provided to help us understand how the worldview of the professionals contributes to the process through which parents construct their stories. Yet the focus (for this article, at least) remains on the stories parents tell and the ways in which those stories attempt to constitute a world in which they and their children might live.

10 This is the name given in New York State to the interdisciplinary school district committees mandated by federal statute. The original act authorizing the creation of these committees was entitled "The Education for All Handicapped Children Act" (1975). As well as making other changes, Congress in 1990 changed the act's name to 
an academic program specifically for their child. In these meetings, the CSE and the parents produce a document known as an "Individualized Education Program" (IEP), " which is, in effect, a binding statement as to the type of education and educational services that will be required in order for the child to receive an "appropriate public education"12 in the "least restrictive environment"'13 during the next academic year. The annual IEP meeting provides the most visible focus for the parents' contacts with the special education system. In these annual rituals, the mythic themes of authority and resistance are reenacted.

The annual IEP meeting is unusual in many respects. The involvement of parents in the academic planning process did not grow out of local customs or practices, nor is it the norm for parents of children who are not considered "disabled." The parents $I$ interviewed were placed in this remarkable position because the U.S. Congress determined in the mid-1970s that direct parental involvement in the planning process was the best means to protect the educational rights of "handicapped" children. The enactment of the Education for All Handicapped Children Act in 1975 (now known as the Individuals with Disabilities Education Act, or IDEA) was intended to reverse the practice in most school districts of ignoring the educational interests and abilities of children with disabilities and of segregating them from their nondisabled peers. Finding that more than half of the eight million "handicapped" children in the United States did not receive "appropriate educational services" and that one million were "excluded entirely from the public school system," 14 Congress mandated the joint planning conference as the mechanism by which an "appropriate education" in the "least restrictive environment" could be achieved. ${ }^{15}$ If parents were dissatisfied with the outcome of the conference, they could make use of a process of appeals that could lead ultimately to the federal courts. ${ }^{16}$

"The Individuals with Disabilities Education Act" (IDEA) (1990) and substituted the word "disability" for "handicap" throughout the text. See 20 U.S.C. $\$ 1400$ (a).

11 IDEA, 20 U.S.C. $\$ \$ 1414(\mathrm{a})(5) \& 1401(\mathrm{a})(20) ; 34$ C.F.R. $\$ 300.342$ (1991).

12 IDEA, 20 U.S.C. $\$ \S 1400$ (c) \& 1401(a)(18).

1334 C.F.R. $\$ \S 300.550-300.556$ (1991). See also IDEA, 20 U.S.C. $\$ 1412(5)(B)$ (requiring that children with disabilities be "educated with children who are not disabled" to the "maximum extent appropriate").

14 IDEA, 20 U.S.C. \$ $1400($ b)(1), (3)-(4).

15 The congressional "mandate" was issued in the context of a spending bill. States seeking money under the Education for All Handicapped Children Act (EHA) had to comply with its provisions. Although in theory a state could ignore the act's requirements and reject the federal funds it offered, in fact every state now complies.

16 Parents with a complaint have the right to an impartial due process hearing, which may be conducted by their local educational agency (in effect, their school dis(rict). The decision of this agency may be appealed to the state education agency, whose decision may then be appealed in the state or federal courts. Some states omit 
After enactment and implementation of this landmark statute, parents suddenly found themselves thrown into a situation for which many felt ill-prepared. As they look around the conference table, they are likely to see teachers, psychologists, therapists, school administrators, nurses, social workers, and doctors. ${ }^{17}$ These professional members of the CSE use language to discuss children with disabilities that is foreign to most parents. Parents find it difficult to understand the specialized evaluation procedures and the jargon that accompanies them. Although it is their child who is being discussed, it does not seem like their child. Aspects of the child that are familiar and important to the parents are not mentioned at these meetings. Their own knowledge systems seem trivial and "unscientific" in comparison to the knowledge systems of the professionals. The parents sense that their comments carry less weight in the CSE meeting because they are not couched in the language of the professionals and because the parents' close relationship to their child makes them seem overly subjective. For these reasons, and because they feel isolated and outnumbered in a conference room filled with members of the professional team, parents are disinclined to advocate effectively for their child.

The parents' situation in the special education system is thus paradoxical. On the one hand, the entire framework of the system rests on the involvement of the parent in the decisionmaking process. The logic of special education law takes for granted that parents will participate effectively. In Board of Education $v$. Rowley (1982), Justice Rehnquist, writing for the majority, asserted that parental involvement in the IEP process provides assurance that the child's program will be "appropriate" because "[p]arents and guardians will not lack ardor in seeking to ensure that handicapped children receive all of the benefits to which they are entitled by the Act" (p. 209). On the other hand, parents themselves feel intimidated and excluded from the decisionmaking process. They feel that their views carry little weight in comparison to the views of the professionals and

the first step of the process, with complaints going immediately to the state level. IDEA, 20 U.S.C. $\S 1415$ (b)(2)-(e)(4)(A); 34 C.F.R. $\S \S 300.510-300.511$ (1991).

17 Federal law requires that the CSE meetings include a specialist in special education, the child's teacher, the child's parents or guardian, and the child "whenever appropriate." IDEA, 20 U.S.C. $\$ 1401$ (a)(20); 34 C.F.R. § 300.344(a) (1991). New York law at the time of the study required in addition that each CSE include "a school psychologist, a teacher or administrator of special education, a school physician, [and] a parent of a handicapped child residing in the school district." New York Education Law $\S 4402(1)(\mathrm{b})(1)(1992)$. This law has since been amended, and instead of "a teacher or administrator of special education," it now requires a "representative of such school district who is qualified to provide or administer or supervise special education." New York Education Law $\$ 4402(1)(b)(1)(1993)$. In practice, I found that the number and identity of the participants in the CSE meeting varied widely according to the customs in each school district. 
that their participation in the meetings is primarily symbolic. Many parents are hesitant to insist on measures that seem to them appropriate, because they lack the training and professional knowledge to justify their position. Although they are present at the meeting because they are laypersons and because they are the child's parents, these become the very reasons why, in their view, their participation has little effect on the IEP conference.

I have sketched this system-and the parents' view of their own role in it-in very general terms. Certainly some parents participate with great skill in the IEP process, and some school districts' committees effectively involve the parents in the decisionmaking process. On the whole, however, my interviews with parents of children who have physical disabilities suggest that the basic statutory premise of parental participation has not, from the parents' perspective at least, been realized in practice. Let us listen to the accounts of ordinary parents, not necessarily those who have taken the unusual step of challenging or litigating with their school districts, and let us consider how their stories of the IEP conference convey a perspective on disability and on parent-professional relationships that is directly relevant to the "origin myths" described in the preceding sections.

When parents were asked to describe their most recent CSE meeting, they generally recounted an experience in which they felt intimidated, anxious, and fearful. They rarely described the CSE meeting in terms that correspond to the exercise in cooperative decisionmaking suggested by the act. Donna Eberle, for example, described her CSE as "a joke":

It's a very long, intimidating table where you're this tiny little dot at one end, and they're all sitting up there at the other end. And some of them are literally almost asleep, and they could care less that they're there. As well as they're telling you, they're delegating orders for your child that they have never seen. They don't know anything about your child other than what they've read and someone else has written. . . And they're telling me all these things that are good for Patricia, that are not good for Patricia, and what they recommend and what they think.

Parents rarely characterize these sessions in terms of a constructive give-and-take between themselves and the CSE members. Rather, they invoke imagery that suggests that they are being judged or punished by the committee. Frank Haefner, for example, observed: "You feel like you're going to the principal's office"; and Ann Haefner added, "You've got this feeling that they've been talking about you before you come into the room. . . Y You can't help but wonder what it was that was said about your family before you came walking in the door." 
Julia Peterson compared her meeting to being on trial before the CSE: "It reminded me of a courtroom or something. It was a real big room, ... . and of course you walk in and everybody else is already seated and you feel so conspicuous and like you're on trial or something. I found it really intimidating." Laura Santoro compared her CSE to a "policeman" and herself to a "pedestrian" and observed that they have "more control" and "more rights" than she does.

The tendency to describe CSE meetings in imagery of judgment or punishment derives not simply from the layout of the room or the numerical imbalance between parents and educators, although both of these factors are highly significant. Parents also feel that they are treated by committee members as "suspects" rather than as fellow decisionmakers. Consider, for example, Elaine Brown's first encounter with her CSE:

We walked in, and everybody is already seated because I think we were a few minutes late. ... I'm starting to walk toward her [the CSE chair], and I had my hand out. And she said, "You, sit over there!". . . After we sat down, she said, "You have a sheet of paper in front of you." And I was looking at her. And she said, "Look down and look at it." I looked down. I just could not believe this. I looked down, and she said, "On that sheet, where I have starred, are all the people that are here today."

Authority and control rest with the CSE, particularly with the chair. Even when parents wish to play their part in the discussion and planning, they feel intimidated and overwhelmed. Suzanne DeMarco said, "I get nervous when I'm with them, because it's 12 against 1." She went on to observe, "When I go to that committee, I'm blown away. I mean, I've got to take a tranquilizer before I go. It's totally intimidating! . . They have these name plates in front of them, and they usually don't even smile at you." Ann Haefner said, "You can cut the air with a knife when you open the door." Frank Haefner added, "It's not a very comfortable feeling when you go in there. It's always like, what are they going to do to us next?"

The sense that "they" are in control and that they do things "to" rather than "with" parents is reflected in Gerry Hagen's comments as well: "You walk into one of these meetings blind. You don't know exactly what's going to happen. ... We always walk into there expecting to hear the worst." Some parents find the stress and intimidation so overwhelming that they simply do not participate. Mary Roth, for example, after repeated disagreements with her CSE, skipped the annual meeting "because I was throwing up. I was so upset at the prospect of having to face all of them that I didn't go."

The feeling of intimidation was expressed by most parents, but there were a few exceptions. One school district was uni- 
versally praised. Its chair, according to the interviewees, was warm, considerate, and sensitive to parents and children. In the words of Jane Hanigan, "Most of the parents at District A have no problems. . . . Generally speaking, it's great out here. . . . Compared to other CSEs, ours is fantastic. I have no complaints whatsoever." The chair of District A's CSE, when interviewed for this study, expressed his awareness that parents tend to feel "threatened" and "frightened." To alleviate these feelings during the CSE conference, he made a point of sitting next to them and writing out the IEP by hand as they agreed on each item.

The chair of the CSE in District B was also aware that parents feel "petrified" at the CSE conference, but she found it difficult to overcome such feelings: "I think we have to be sensitive to this, but I understand that's how they feel. What else can we do?' Parents' perceptions of CSE meetings in District B differed greatly from perceptions in District A, largely, it seems, because of the contrasting attitudes of the two committee chairs. Whereas the chair in District A attempted to involve the parents in the decisionmaking process from beginning to end, the chair in District B saw her task as attempting to "persuade" parents to "accept" the recommendations made by the professionals. In this regard, she observed that "fathers can be more easily persuaded" than mothers, whom she saw as preoccupied with unimportant details. Since mothers participate more frequently in CSE meetings than fathers, the CSE's job of persuasion is often difficult:

Women are picky. Okay? They are, they're fussy. . . . Moms want to pick, pick, pick, pick. And I don't say that in a derogatory-I'm talking about myself. But they're at every petty little detail. . . . Take a look at the difference between a female teacher and a male teacher. A male teacher can see it nice and big. And a female teacher, I mustn't categorize them all, they're at every little-you know what I mean? Come on, be honest. Okay? You like that, don't you?

The CSE chair in District B responded to "pickiness" with some impatience, and parents reported that she often appeared hostile when they raised questions or made suggestions. Feelings of intimidation were strong among parents in District B and tended to focus on the personality of the CSE chair.

Parents' negativity toward the CSE process reflects feelings of intimidation such as those described above, but there are other areas of dissatisfaction as well. A recurring parental complaint is that the CSE knows little about their child, yet reserves the right to make important decisions without considering the parents' insights. Ann Haefner asked, "Do they have a face to even connect with these records? That would be nice, if they knew who they were were talking about." Some parents bring 
photographs of their child to the CSE meetings to remind the committee members that there is a real person behind the impersonal discussions and assessments. Some parents assume that not knowing the child equates to not caring about the child as a person. They share the feeling Jennifer Kuhn expressed about her CSE chair: "She could care less. That's my feeling of her is that she could care less." This is one allegation, by the way, that CSE members deny categorically. They feel that their decision to enter the field of special education signifies that they do care about children with disabilities and want to work for and with them.

The parents' perception that the CSE does not care about their children is closely linked to the perception that the CSE does not care about the parents and their potential contribution to the IEP. Frank Haefner, recalling the CSE's failure to respond to Ann Haefner's suggestions at the meeting, observed:

They just gave you your time to speak, and then they did what they wanted to do anyways. They have that impression of just being a big machine, and you can go in there and you can blow off steam and say whatever you want. And then they're going to do what they basically want anyway. You really don't have a whole heck of a lot of control over what's going on there.

The perception of the CSE as a "big machine" that will grind out its decisions regardless of the parents' contribution is widely shared. Julia Peterson, for example, observed:

They really don't care what you have to say. They're going to make up their minds according to the way they've done things and they all agree to do things. ... I just think it would be nice if they were real receptive and maybe would listen to some of the parents' ideas.

Suzanne DeMarco agreed: "I don't think parents have any say." Joyce Majewski noticed that her CSE listens to her only as long as she agrees with the decision they have already made. "But the minute you question them on anything, they don't like it."

To some extent, as we have seen, the CSE chairs confirm the perception that parental opposition to CSE recommendations is unwelcome. Rather than viewing the IEP process as one in which the parents should participate from the beginning, they view it as one in which the professionals should formulate recommendations beforehand and parents should give their approval at the meeting. The challenge facing the professional members of the committee is thus to persuade the parents to accept their determinations. For example, speaking in particular of the initial placement decision, the CSE chair in District C observed that the basic goal is to "try to get the parent to approve that placement that is recommended, that will be recom- 
mended by the CSE. If that doesn't happen, it leaves us in a dilemma. What are we going to do?" It is easy to understand why CSE professionals could become frustrated if parents were "picky" about accepting their recommendations. As the CSE chair in District D stated: "They come to us for educational services and educational advice, based on our experience and knowledge of options, I would expect that they would follow what we have to say."

From the perspective of the participants in the CSE process, there is a tension between the statutory model of cooperative planning envisioned by the congressional drafters and the more familiar model of expert recommendation and parental consent that is, perhaps, a product of the traditional culture of professional-client relationships. Parents tend to experience this tension as exclusion from the decisionmaking process. Professionals tend to experience it as occasional parental obstinacy or meddling in matters they are ill-equipped to understand. During my interview with two CSE members from District E, there was a moment when their perspective on "persuading" parents emerged with particular clarity. At this point in the interview, the two administrators turned and debated with each other the advantages and disadvantages of working with "educated" parents:

A: An educated parent is much easier to work with.

B: And I won't agree with you. Isn't that funny. . . I do not want a very uneducated person. I find those are difficult to work with, because now you've got to do so much background work you hoped was taken care of before you got to Committee.

A: But their experience, the ones who are not really well versed or well educated have had bad experiences with schools themselves, so they don't trust the school.

B: Right.

A: No matter what you tell them, they're sure that you're pulling a fast one on them.

B: But a very educated parent is working in, I'm sorry to say, almost hostile to you. Whether the experience is coming from a previous committee that they've dealt with, whether it has been from private testing that they have done on the child, whatever it is. They have come in with the attitude of, I know the law and this is what I want and you will give it to me.

A: Well, I would rather deal with educated, but not hostile.

B: Okay, but I have found that today they're almost getting too educated the wrong way.

The dialogue swings back and forth, between apprehensions about the parent who understands so little of what is being recommended that consent becomes problematic and apprehensions about the parent who understands (or thinks she under- 
stands) so much that she can dictate her preferences to the committee and threaten legal action if the committee resists. What does not emerge from this dialogue is an image of parents-whether "educated" or uneducated-as partners in the deliberations and as coequals in the process of cooperative decisionmaking.

The congressional objective of early parent involvement in the planning process has led to frustration on the part of both professionals and parents. To the extent that parents feel relegated to a role of stamping approval on decisions made without actually considering their views, they would not agree that the congressional purpose has been achieved simply because they have been given a seat at the CSE conference table. Yet when parents participate more assertively in the committee meeting, they run afoul of professional expectations that have been conditioned by traditional models of expert recommendation and consent. In School District A, where parents were so effusive in their praise of the CSE chair, Jane Hanigan said that the CSE chair made a point of asking her after each recommendation, "Mrs. Hanigan, do you agree with that? Do you really think that's the best for Don?" This approach is, however, the exception rather than the rule, and most parents come to feel that their views carry little weight during the CSE meeting. Rather than viewing the meeting as an occasion to share information and work cooperatively to shape the "appropriate education" mandated by the act, parents experience the IEP conference as a tense, alienating, and intimidating experience in which they are subjected to the authority of the professionals on the committee and are effectively excluded from the decisionmaking process.

It is worth noting that the special education professionals' approach closely resembles the model generally associated with the provision of medical services. Indeed, the chair of the CSE in District F explicitly compared decisions about special education services to those dealing with medical services. ${ }^{18}$ Such comparisons have great significance for interpretation of the "origin myths" discussed above, in which doctors substitute for special education experts. The parallels between the two types of stories suggest that, in the parents' view, the "medical model" operated in the past as it operates in the present to produce a sense of exclusion and intimidation. Retelling the origin story implicitly draws the thematic comparison even as it affirms the parents' desire for a relationship based on greater mutuality and respect.

18 See statement by the chair of District F's CSE, infra at p. 808 . 


\section{Two Ways of Seeing and Talking about Children with Disabilities}

If a lion could talk, we could not understand him.

-Ludwig Wittgenstein, Philosophical Investigations

(1968:223)

The encounters between parents and professionals at the annual IEP conference, like the encounters between parents and doctors described in the origin myths, are "events of articulation" (Moore 1977:159); they are defining moments in which roles, norms, and meanings become unambiguously apparent. They epitomize a set of relationships and experiences, however, that go far beyond the brief interaction around the CSE conference table. Parents sense that their worldview and their understanding of their child differ fundamentally from those of the professionals with whom they must deal. They sense, as well, that these differences obstruct communication and lead to divergent conclusions about who the child is, what her future could be, and what programs are appropriate for her. Moreover, the different worldviews of parents and professionals are, from the parents' perspective, associated with significant power imbalances, which grant superior authority to the conclusions of the professionals and place the parents in a position of-at best-resistance to the established framework within which children with disabilities are "treated" and educated.

As described in the narratives of the parents and educators I interviewed, professional knowledge about the child is grounded in insights obtained through brief, intense, controlled, diagnostic encounters between child and professional. Often the professional is a stranger to the child: knowledge of the child outside the evaluational context is not necessary in order to administer the battery of tests on which the CSEs typically rely. Reports from teachers and therapists who know the child may supplement the standardized quantitative evaluations, but even these reports often strain to apply objective, scientific measures rather than subjective, anecdotal observations. Validity, in this knowledge system, rests on quantitative comparisons of the child's performance to that of a preestablished set of norms derived from the performance of other children. "Truth" is subverted by personal knowledge or attachment or by the parent's poor adjustment (from the professionals' perspective) to the child's disability. As the CSE chair in District C observed: "A lot of parents make decisions based on their own needs, not the needs of the kid. And this is one of the problems I have in dealing with parents." Professionals must cut through the fog of emotionalism and subjectivity to the "hard" reality of 
objective findings. The necessity for scientific objectivity is especially great when dealing with children with disabilities, since emotions run so high and people's hopes and wishes can so easily prevent them from coming to terms with painful truths.

The documents in the child's file are artifacts of the professional worldview. Professionals assume that these documents will be difficult for parents to understand, not only because parents are influenced by "denial," anxiety, and subjectivity but because parents lack technical training in the field of special education. As the well-known and influential CSE chair in District $F$ told me:

I think this law has forced [parents] into thinking that they could really have a true partnership with the professionals. . . . But I think personally it's somewhat unusual to expect. It's like saying to you, you can have a partnership with the doctors who are going to treat you. You should have just as much say in all of your treatments. You can't really have as much say because it's too complicated.

We need not consider the implications of this statement for the involvement of patients in medical decisionmaking. The implications for parental involvement in the IEP process are clear enough. The same CSE chair went on to say:

If we don't really understand the different parts of the brain and all the memory things and the processes, especially the learning-disabled children, how can a parent really say what should be done? I don't think parents can do quite as much as ... Albany thinks that they can.

It is probably not surprising to find that some parents share the view of this CSE chair. They, too, feel that the issues are simply too complicated for them to understand, and they assume that the professionals will "know best." Although they know their child well, their knowledge is not the kind that counts or should be considered. It is based "merely" on everyday experiences and observations, on qualitative assessments, and on affection, intuition, and aspiration.

Some parents, however, experience great frustration with their inability to convey the validity of their own knowledge system during their interactions with professionals. In this clash of epistemologies, parental frustration can be expressed in a number of different ways. One way is to argue that "superior" education and professional credentials do not automatically qualify the CSE members to make decisions about one's child or disqualify the parent from having a significant voice. This is Gail Schreiber's view:

You can have your Master's, you can have your Ph.D., and you put all of this education, which is good-but nobody knows everything. Some of these people just don't like to be told that they don't know everything, that they could be 
wrong. And that's where a lot of problems start. [Q: Why do they feel that they "have all the answers"?] Because they're professionals, and they're experts in child education. And you're a parent and, like me, I've never gone to college. . . . But I'm still the child's mother. I live with her 24 hours a day. I know what upsets her; I know what makes her happy. And just because you've got this stuff written on paper does not make you right and me wrong.

The Schreibers had opposed their CSE's recommendations and, after a struggle, had ultimately prevailed. This led Gail Schreiber to the conclusion that parents had to resist the assumption that those with the superior credentials should make the determinations: "Unless you open your mouth and you fight, you have no say on what goes on with your kid. They could put your kid in Timbuktu if they wanted to."

Many other parents concurred with this view, which finds its counterpart in the version of the origin myths in which the doctors refused to listen to the mothers' concerns about their babies' development. Such parents asserted that their perspective, while different from that of the professionals, had its own legitimacy. Christine Campo, for example, acknowledged that "a lot" of parents defer to professionals because they are better educated and should know better, but she felt that was simply "baloney": "If nothing else, I found out, nobody knows better than you." While the judgment of professionals should be considered, she believed that she knew what was best for her child. Although cloaked with the mantle of professionalism, the specialists are merely human and are far from infallible:

The one time I sat there and I looked [around the conference table], the psychologist was a man about town who didn't have his children living with him. ... The person who was head of the Committee on the Handicapped, and still is, is unmarried, doesn't have any children. I just looked around the table, and not any of them, for one, had children living home, or did any of them have a handicapped child. And yet, they're telling me, "Well, Christine, you have to do it this way." That condescending attitude, like. And it took me a few years to finally realize, who do you think you are telling me how I should deal with these problems?

There is an "emperor's new clothes" aspect to the discovery that the CSE members are not only fallible persons whose judgment may be questioned for many reasons, but that some of them actually know little about children with disabilities. Angela Rose was surprised to learn, when she became a parent member of the CSE, that the intimidating chair of her committee was actually less informed about disability issues and special education than many parents. Arlene Koch, another parent member of the same CSE, visited a classroom for "severely involved" children with the CSE chair and was surprised to see 
how awkward and unfamiliar she was with children who had severe disabilities: "She was so uncomfortable. She was almost jumping out of her skin to see kids that had to be fed. It was obvious that she didn't have a lot of exposure to severely handicapped children."

Parents find great significance in such observations. On the one hand, the observations underscore the important fact that parents' practical experiences with their own children provide a fund of knowledge and information that the CSE professionals-who, in these stories, were childless or unfamiliar with children like theirs-simply lacked. In this sense, then, parents are able to portray themselves as more knowledgeable than the professionals, not less. Further, such stories provide a basis for asserting that the knowledge system of the professionals must be supplemented-or countered-by a different kind of knowledge system based not on science but on their own experiences and common sense.

Parental resistance to professional authority thus finds expression in stories that show the professionals are merely human, that they have their own personal problems, that they lack practical experience with disabilities, that they are awkward or frightened when in the presence of the very children for whom they so confidently pronounce judgments about educational programs and placements. Resistance is sometimes expressed in another, even more subversive, type of storytelling. In these accounts, parents show how the very act of professional evaluation can be an exercise in foolishness. Such stories place the artificiality of the testing process in opposition to the common sense of the parent-observer. Ruth Mueller, for example, recalled Jon's first interview with a psychologist. Jon was tired and not in the mood for the tests the psychologist insisted on administering. Finally, he gave Jon an ugly old doll with its arms, legs, and head taken apart and told him, "Okay, Jon, put everything where you think it belongs." Jon promptly threw the whole doll in the garbage can. Ruth Mueller laughed and thought to herself, "God, he's smart."

The point of the story, for Ruth Mueller, was that Jon's clever response had triumphed over the artificial routines of the psychologist but in ways that the specialist could not measure-or even understand. A somewhat different point emerges from a story told by Joyce Majewski about a psychologist who drew far-reaching conclusions about her son, Bryan, from the picture Bryan chose to draw during his evaluation. Bryan, who was a sports fan, drew a careful portrait of a hockey goalie. The psychologist concluded that Bryan's decision to draw a mask on the goalie indicated that Bryan hid his feelings just as the goalie hid his face. Joyce Majewski argued that this conclusion was ridiculous and was unsupported by the opinions of anyone else 
who knew or worked with Bryan. The commonsense explanation was that goalies are often heroes to children in this city of avid hockey fans, and goalies always wear masks when they play. A child would no more draw a goalie without a mask than a football player without a helmet and face guard. Joyce Majewski's anecdote makes the psychologist look foolish because the specialist tried to find deep, complex meanings hidden in behavior that is readily understandable to anyone with any sense.

In stories like these, parents convey a view of the world reminiscent of the view contained in the "origin myths" discussed earlier. They contrast the ordinary, everyday world of experience and common sense to the overly theorized, impractical, and sometimes silly world of psychologists and professional educators. It could be argued that Mueller and Majewski were indeed guilty of a failure to understand the methods and concerns of the professionals. Whether a child with disabilities really does understand where the different parts of the body "go" or really does hide his feelings may be important and difficult questions. Perhaps the parents were insufficiently sensitive to their significance. From the parents' perspective, however, such questions should be approached in a less artificial way and the answers should be grounded in the concrete realities of the child's day-to-day life and the insights of those who know the child best. Instead of asking a cranky child to "play" with a dirty, unfamiliar doll while a stranger watches and takes notes, why not have a conversation with Jon's parents and teachers or observe Jon in his own environment? Instead of concluding from a single crayon drawing that Bryan hides his feelings, why not talk with Bryan and his family and teachers about how he expresses or withholds feelings-and about his perception of hockey goalies? The methods of the professionals fail, in these narrative accounts, because they deliberately exclude consideration of the world of the parents and the child in favor of simulation and laboratory-like test conditions.

The exclusion of the parents' world and worldview, according to these stories, exposes the professional to the risk of overinterpretation and foolish violations of common sense. It also contributes to the disempowerment of parents, since the interpretive framework of the specialist rather than that of the parent provides the basis for CSE decisionmaking. There is another consequence as well. Whereas parents tend to perceive the whole child and to emphasize capabilities, the professionals tend to perceive the child in terms of "defects"- those aspects of the child that deviate from the norm and justify the child's classification as "handicapped" or "disabled." The defects are the basis for professional intervention; the defects are the raison d'être of the CSE meeting, and the CSE committee itself; the defects are the reason the law requires "special" edu- 
cation and remediation. The CSE's emphasis on "defects" can convey a highly negative message to parents, according to the CSE chair in District G:

Unfortunately, most of the things that you say are negative. You're saying all these things about this person's child, and it's very hard. At first there are many, many positive things on the other side of the coin. But you want to get a point across that your child needs help, and your child's not doing this and your child's not doing that. So sometimes it seems very negative. And we don't mean to be that way, but I can understand how frightening it must be.

The contrast between the parental view of the whole child (or the child in the context of the world in which she lives) and the professional focus on the child in terms of "defects" is suggested, indirectly, by a passage in Oliver Sacks's book, The Man Who Mistook His Wife for a Hat (1987). Sacks, a neurologist and specialist in brain dysfunction, recalls that he had examined a patient named Rebecca in the hospital. Acting in his professional role, he had perceived Rebecca "as a casualty, a broken creature, whose neurological impairments I could pick out and dissect with precision" (p. 180). Rebecca's performance on the tests was "appalling," but, by chance, Sacks later encountered her in the hospital garden on a beautiful spring day. Here, she seemed entirely different: smiling, composed, taking pleasure in her surroundings. She greeted Sacks and gestured toward the lovely foliage. She spoke to him in disjointed but poetic phrases:

'spring', 'birth', 'growing', 'stirring', 'coming to life', 'seasons', 'everything in its time'. I found myself thinking of Ecclesiastes: 'To everything there is a season, and a time to every purpose under the heaven. A time to be born, and a time to die; a time to plant, and a time ...' This was what Rebecca, in her disjointed fashion, was ejaculating-a vision of seasons, of times, like that of the Preacher. 'She is an idiot Ecclesiastes,' I said to myself. And in this phrase, my two visions of her-as idiot and as symbolist-met, collided and fused. (Ibid.)

Sacks ponders the question why these two "visions" of Rebecca could be so different. His answer implies that it is not simply that Rebecca is both "idiot" and "symbolist" but that Sacks himself "knew" Rebecca in two different ways and saw her in two different settings. The neurological and psychological tests had been designed "not merely to uncover, to bring out deficits, but to decompose her into functions and deficits." Emphasizing pattern perception and problemsolving, they "had given no inkling of anything but the deficits, of anything, so to speak, beyond her deficits" (p. 181). The tests he had ad- 
ministered had provided no insights into the young woman he had encountered in the garden:

They had given me no hint of her positive powers, her ability to perceive the real world-the world of nature, and perhaps of the imagination-as a coherent, intelligible, poetic whole: her ability to see this, think this, and (when she could) live this; they had given me no intimation of her inner world, which clearly was composed and coherent, ... [when] approached as something other than a set of problems or tasks.

(Ibid.) ${ }^{19}$ (Emphasis in original)

In this passage, Sacks experiences and conveys both sides of the dichotomy. His view of Rebecca in the examination room, he suggests, typifies a professional perspective based on test procedures designed to evaluate deficits; his view of Rebecca in the garden, on the other hand, approximates the perspective of parents who draw on everyday insights and experiences in the world. It is rare for any one person to understand both perspectives. More commonly, parents and professionals talk past one another and fail to agree on who the child is whose fate rests in their collective hands. This is a more profound problem than parents' simple inability to understand professional terminology or concepts. Parents sense that the child they know is an essentially different person from the child discussed by the professionals at the CSE meeting. One might visualize this collision of conceptual worlds by imagining Rebecca's parents trying to convey her personality and her capabilities-as they saw them day after day in her natural environment-to a diagnostician who had not had the benefit of Sacks's accidental observation of Rebecca outside the examination room. It is unlikely that the parents could find words to convey this reality to the professionals, or that the professionals-no matter how sensitive to the problem of appearing overly negative about the child-could understand the significance of what the parents were trying to tell them. The two worlds of the parents and the professionals would remain separate, and within those two worlds, two very different Rebeccas would exist.

For which of the two Rebeccas should the IEP be written? This was not the issue in the case Sacks describes, of course, but it is the issue for the millions of school-age children who are the subjects of CSE meetings across the country each year. The IDEA has little to say on this issue. It does preclude CSEs from basing their evaluations on any single test, ${ }^{20}$ and it does protect the right of the parents to participate in the meetings and appeal adverse decisions. Yet there is nothing in the act

19 The bracketed word "when" is used here to correct an apparent typographical error in the original text.

20 IDEA, 20 U.S.C. $\$ 1412(5)(C)$. 
that requires the CSE to focus on "positive powers" rather than deficits, on the "composed and coherent" inner worlds of the children rather than the difficulties they experience when they encounter human society in its various forms (including the testing routines contrived by disability specialists). There is, in short, nothing in the act that gives special legitimacy to the parents' version of the child rather than the professionals' version.

The frustration parents experience at the CSE meeting derives ultimately from this sense that the child they know is never really brought before the committee. This is what they mean when they emphasize repeatedly that no one on the committee knows their child and that no one really listens to them. This is why they sometimes bring photographs of their children to the annual meeting-a vain attempt to convince the CSE members that there is a different reality out there that has escaped the committee's attention, a different child who has not been adequately described by the terms and concepts employed in the CSE discussions. Yet parents sense that every attempt they make to convey this different reality to the committee results only in a confirmation of the professionals' perception that the parents are essentially emotional, subjective, and incapable of understanding the scientific basis of childhood disabilities and special education.

\section{Law, Power, and Participation}

"That's all, and life went on." ... "No. There's still something in my heart about this that isn't finished. My heart is still shaking. The story hasn't come completely out. I'm going to talk more about it until it does. Then, I'll go on to another. Then, my heart will be fine."

\section{-Nisa in Marjorie Shostak, Nisa: The Life and Words of} a !Kung Woman (1983:40)

If, as I have suggested, the parents of children with disabilities construct the world differently from the professionals with whom they must negotiate in the IEP meeting, one might ask why the parents' interpretations and preferences do not prevail more often. The parents seem to hold a trump card: the right to request an impartial hearing when dissatisfied with a CSE decision, the right to appeal the hearing officer's decision to the State Education Department, and the right to take their case to federal district court if unhappy with the results of the hearing process. In short, parents can consult lawyers and invoke the law, which was written to protect their interests and to ensure that their view of the child is heard by the CSE. In theory, these legal protections should redress potential power disparities between parents and professionals. Since hearings are 
very costly to school districts and parents may have access to various types of no-cost legal services, the law should actually place parents in an advantageous position. Even in the cases where parents do not seek legal counsel, the knowledge that they might do so should equalize the balance of power.

The parents' accounts suggest, however, that their due process rights have little effect on the IEP conference, except in those rare cases where the parents actually bring an advocate with them. In large part, this is because many parents simply do not know the law and have no idea what rights they could invoke. They assume that the CSE provides them and their child with all that the law guarantees. Others are less trusting but sense that legal confrontation with their own school district could be viewed as antisocial or, at the least, could disrupt an important relationship that must continue as long as their child remains in school.21 Those interviewees who did give some consideration to consulting an attorney usually decided not to take what they considered a drastic step.

The triggering event causing a few parents to overcome their reluctance to wage legal battle differs from one case to the next. One of the most revealing stories was told by Mary Roth. Roth had engaged in a series of skirmishes with her CSE. Some of the professionals insisted that her son, Tim, was "mentally retarded," while Roth maintained that he was "learning disabled." This basic disagreement led to conflicts over classroom placements. Eventually, Roth went for an educational evaluation by an independent center. She was told that the center's social worker would be contacting them to initiate the evaluation. This pushed Roth and her husband over the edge and led them to the Education Law Clinic. It was not just that the Roths did not like social workers. They felt strongly that they did not "need someone snooping into our lives."

Roth felt that the involvement of the social worker was symptomatic of a general attitude by the professionals that children with disabilities (and their families) were automatically fair game for intrusive and demeaning interventions that would never be tolerated in cases involving children without disabilities:

If a child is not handicapped, the social worker doesn't come by and say, "What are you doing with your children?" ... What makes my son, because he has a learning disability, any different than any other child? You're singling them out, and I don't believe in that. . . . Treat them like a human being. I don't like social workers at all. I don't like that type of prying. If I need help, I'll ask for it. That's why we went to [the Education Law Clinic].

21 See Engel (1991:194-203), where the problems of rights assertion are discussed at greater length. 
Mary Roth viewed the intervention of a lawyer on her behalf as an alternative to the unwanted intervention of a social worker. The social worker, she felt, was not working in her interests but continued a series of interactions with professionals that she found degrading and irrelevant. She wanted someone who would get Tim what he needed and deserved, not someone. who would, in her view, unnecessarily pry into the private concerns of the family.

Roth's story highlights an important relationship between the parent-professional dichotomy (discussed in the preceding section) and the involvement of attorneys and advocates. For the Roths, the degrading ministrations of the social worker confirmed a more general sense that the professionals made their family the passive objects of the evaluation and service delivery process. What the Roths wanted, on the other hand, was to be active participants whose role was roughly comparable and equal to that of the other participants. The only way they found it possible to transform their status from that of object to participant was to engage the services of a professional advocate. By this means alone, they acquired the power to be heard when they articulated preferences, expressed opinions, and tried to safeguard their child's rights.

Even when an attorney does not initiate a hearing or appeal, from the parents' perspective his or her mere presence at the CSE meeting makes a significant difference. Parents note that, in the presence of an advocate, the CSE members become more attentive and courteous. Mary Ann Young observed that when her advocate spoke to the CSE they listened, but when there was no advocate present and she said the same thing to them, "I'm an aggressive mother; I don't know anything." Arlene Koch decided to bring her son with her to a CSE meeting that her attorney also attended. The combined presence of child and advocate changed the tone and dynamics of the meeting completely:

Totally different and genuine. Now it's like, "Oh, well, Mrs. Koch" . . "They were so apologetic, and they kept saying, "Oh, Mrs. Koch, we didn't realize that he was this involved." And I thought, "Hasn't anybody seen this kid?" He is almost 10 years old, and it really seemed like nobody had ever seen him.

Christine Campo felt that the involvement of an attorney not only changed the tone of the meeting but tipped the balance of power in her favor for the first time:

They kind of gave me power and the knowledge to know that, yeah, I can fight City Hall. Before that, I thought I was just one parent in the wilderness and accepting what they were giving, until I found that ... they have to provide him with a full day of school, they have to provide adequate busing. 
The few parents who use an attorney may feel that they have corrected the power imbalance between themselves and the professionals and that the attorney enables them to participate in the IEP process with greater effectiveness. CSE members, however, view the involvement of attorneys in very different terms. A distinct minority of the CSE chairs I interviewed spoke of the involvement of attorneys positively, as an opportunity to introduce new perspectives and new sources of information as well as an opportunity to alleviate parents' fear and stress. ${ }^{22}$ The CSE chair in School District A, whom parents praised for his openness to parental involvement, observed that while some advocates are "unreasonable" or are "on a power trip," they can play an important, positive part in the CSE process:

I think that they have a lot of expertise to offer, and also they're there to protect the kids' rights and a parent's rights. And I think that's important, too, because many times they can be lost by different committees. . . I've learned a few things from advocates and attorneys and other professionals who deal with testable kids and making recommendations for programs. ... I think the input is good. And I think the interpretations of testing data are good, and also they can offer you availability of other programs that, maybe, being in a little rural area, you just don't know about.

The majority of CSE chairs, however, feel that there are significant drawbacks to the involvement of advocates in the IEP process. The CSE chair in School District $H$, for example, noted that advocates tend not to know the child as well as the CSE members do, and he complained that advocates could "intimidate" and sway committee members who fear the possibility of a hearing. The CSE chair in District I commented that the participation of an advocate introduces an element of legalism that makes things "very, very difficult" for the committee. The CSE chair in District J observed that committee members tend to take it personally when an advocate supports a parent's objection to a CSE's recommendation, particularly when the CSE feels it has already "bent over backwards" on the child's behalf. The CSE chair in District $K$ noted that some advocates approach matters in a positive way but others "come in with an axe to grind." $\mathrm{He}$ and the other members of the committee "really bristle sometimes if an advocate comes in with 'thou shall do this and thou shall do that, and you guys are screwing up and this is the way that it will be." "He resents it when advo-

22 I must mention that all CSE chairs I interviewed were aware that I was on the faculty of the State University of New York at Buffalo Law School, which sponsors the activities of the Education Law Clinic in special education cases throughout Western New York. It is possible that this shared institutional affiliation affected the comments that CSE officials made about the role of lawyers and reduced their criticisms. Even so, as we shall see, their comments tended generally to be negative. 
cates unnecessarily create an "adversarial relationship." However, he concluded, "We don't mind advocates coming in."

Some CSE chairs I interviewed were unequivocally angry about the role of attorneys in the special education process. The CSE chair in District $\mathbf{E}$, for example, was furious that an advocate had succeeded in having an external recommendation implemented so that a child received therapy five times per week. The CSE had concluded that no therapy at all was necessary: "In other words, she's pulled out of her class five times because of all these do-gooders who are really upsetting the apple cart." The CSE chair in District B maintained that the involvement of an advocate was an implicit statement that "Evidently, the parent doesn't trust us. ... They have to get somebody to protect their rights because we're going to violate them." The presence of an advocate changes things markedly for the worse: "I think immediately it sets up a poor tone. It tends to be a very negative tone. . . . Pretty soon, they've forgotten all about the kid and nobody even remembers that there's a kid out there."

Perhaps most intriguing were the CSE complaints that intervention by an advocate tends to formalize the annual meeting and chill what is otherwise a warm and harmonious atmosphere. Even the CSE chair in District A complained that with an attorney present the atmosphere becomes "very formal and cold." Others said that the focus of the CSE shifts toward dotting all the i's and crossing all the t's. ${ }^{23}$ The CSE chair in District $G$ voiced a recurring complaint when she observed that the presence of an attorney impedes direct communication between the committee and the parent: "The few times that we've had a lawyer or an attorney, the parent will not share their feelings. So right away, we have no idea what the parent thinks."

This type of complaint is particularly significant. The CSE members dislike the sense that they cannot communicate directly with the parent but must speak through an intermediary. When an attorney attends the CSE meeting, in the words of the chair from District J, "the parent doesn't say boo; the advocate says it." To counteract this problem, she makes a point of speaking directly to the parents and asking for their views.

For the professionals who are members of the CSE, the involvement of attorneys disrupts direct communication with parents and chills the warm feeling and openness that they feel otherwise prevails in IEP conferences. For parents, by contrast, the involvement of attorneys helps to counteract what they perceive as the cold formality and intimidating tone of the IEP conferences, during which their opinions are seldom solicited and their voices seldom heard. The disparity between the per-'

23 E.g., Districts E and L. 
spectives of parents and professionals could not be more striking. Since their perceptions of the tone and character of the IEP meetings are totally different, they reach opposing conclusions about the transformative effects of bringing lawyers into the process to protect the interests of parents and children.

Implicit in the CSE complaints about advocates is an assumption that when parents attend without representation, the meetings are generally informal and the parents contribute freely and effectively to the decisionmaking process. How can this assumption be reconciled with the parents' perception of intimidation, formality, and unwillingness of the professionals to listen to them? It appears that parents and CSE members mean different things when they speak of formality and of parental participation. The parents feel that the presence of an advocate is indeed consistent with their own effective participation in the CSE meeting, since the CSE, from the parents' perspective, usually does not hear or understand their views unless expressed by a fellow professional-in this case, the attorney. If the advocate were not there, the CSE members could speak directly to the parent but this, in the parents' view, would inhibit and not enhance communication, since the parents' responses would probably be disregarded. What the professionals experience as meaningful communication is experienced by the parents as domination and rejection. What the professionals consider a mutual and cooperative decisionmaking process is viewed by the parents as a unilateral exercise of power and authority. Nor would the parents agree that the presence of an advocate creates greater formality, since the ordinary workings of the CSE are already interpreted by them as "formalistic."

CSE members seem to mean something different when they speak of formalism and informalism. They are undoubtedly familiar with contemporary theories of mediation and group consensus building which emphasize that it is important for all participants to speak openly and honestly (to "vent") before a decision is reached. Yet the application of such principles is highly problematic in the context of drafting a child's IEP. There is an asymmetry to the IEP conference that arises not only because the parents and professionals speak different languages and view the world through different lenses, but also because their status at the conference table is fundamentally different. In the CSE meeting, one party enters the discussion with control over resources while the other has only needs and rights. The party with control over resources-the CSE-has no needs or emotions to "share" or to trade, just as the party with needs and emotions-the parent-has no resources to offer in the negotiations. The negotiating process for the parent is, therefore, a matter of attempting to bargain for resources by citing needs-a frustrating and sometimes humiliat- 
ing process. As we have observed, the bargaining process is further skewed by an unequal access to the language and the information system in which needs must be articulated in order to justify the expenditure of resources.

When the principles and methods of informalism are employed in this context, it is not surprising that one party-the parent-would experience the meetings as formalistic and oppressive while the other party-the CSE-would experience it as informal and open. These differing perceptions help to explain why advocates are perceived so differently when parents rely on their services. For CSE members, advocates who speak the language of rights and procedural regularity destroy the possibility of informalism. For parents, advocates translate subjectively felt "needs" into objective bargaining counters"rights" - that can be traded for resources. They not only speak the language of the professionals far more fluently than the parents could, but they have sufficient facility with the legal framework of the decisionmaking process to force the CSE to consider the parents' bargaining position or risk a costly due process challenge. Lawyers, in a sense, reverse the positions of the conference participants and, by virtue of their own esoteric knowledge system, place the educators in the position of the disempowered "layperson." ${ }^{24}$ For CSE members, advocates chill and inhibit interpersonal dealings; for parents, advocates liberate, empower, and protect the fragile interests of their children.

Parents, we have said, seldom use or even consider using advocates. For most parents, the differences between their worldviews and those of the professionals remain irreconcilable, and the special education process is, by and large, an exercise in frustration and alienation. Even when parents do use lawyers, however, the enhancement of their bargaining power is not necessarily matched by a reconciliation of conflicting worldviews. Although parents with an advocate are far more likely to achieve the results they want for their children, the transformative effects of the lawyer's involvement are interpreted differently by parents and professionals in the CSE process. The invocation of law tends to confirm disparities in the perceptions of parents and professionals rather than to reconcile them.

\section{Beginnings}

Through the unknown, remembered gate

When the last of earth left to discover

Is that which was the beginning.

-T.S. Eliot, "Little Gidding" (1952:145) 
We have moved backward and forward in time, from narratives of "beginnings" to narratives of the present. These stories transcend time: the "origin myths" are rich with implicit references to recent events, and the narratives of current experiences incorporate much that came before. By exploring such stories across time, I have attempted to explain the origin myths and to decipher their meanings.

The parents who tell these stories perceive the world in terms of a set of oppositions that originate in the diagnosis of their child. Before the diagnosis, some parents explained to me, their dream was the conventional vision of a "normal" family in a house with a white picket fence. After the diagnosis, their vision changed. Their child was defined in opposition to other children, their aspirations in opposition to the child's predicted future, their wishes in opposition to the recommendations of educators and other specialists. They found themselves on the other side of a divide separating them from the ideals and institutions of mainstream American society. The transformation from a holistic to a divided and oppositional consciousness is one of the most important meanings to be found in the origin myths and is associated in the myths with the trauma of the diagnosis itself.

If we examine these oppositions more carefully, we find first, and most obviously, an opposition of professional and parent. In the origin stories, the professional is a doctor. As the child grows older, parents must deal not only with doctors but with other professionals who specialize in evaluation and programming for children with disabilities. Some are medical specialists, some psychologists, and some educators. For the parent who tells the origin stories, the original doctor stands for all these professionals. The stories attempt to show that the professional does not listen to or care about the parent. The professional, in these stories, rejects the parent's views and emotions and speaks the cold language of science. The professional values objectivity above all else and assumes that the parent's concerns are subjective and thus of lesser importance than the insights of the specialist. The origin stories also show, however, that the professional was wrong about the child. Exclusive reliance on science and rejection of the parent's common sense and intuition, these stories suggest, lead to erroneous conclusions about the child and the future. The origin stories are meant to show that the child's accomplishments have far exceeded the original diagnosis and that the parent's insights have ultimately triumphed over those of the professional.

The origin stories encode other oppositions as well. The opposition of authority and subordination versus participation-which the parents experience so vividly in the IEP con- 
ference-is implicit in the mythic depiction of the medical specialist dominating the parent, who is the "victim" in the encounter. The Campos, for example, convey this sense of helpless victimization when they compare the delivery of the diagnosis to being shot again and again by the doctor, ${ }^{25}$ and Mary Roth and others convey their inability to participate in interactions with professionals when they describe how the doctors refuse to listen seriously to their concerns over the child's development.

The origin myths thus encode a set of oppositions-professional versus parent, science versus common sense, objectivity versus subjectivity, authority versus participation-that are relevant not only to the original diagnosis but also to the parents' later encounters with professionals, particularly in the context of the special education system. How should these striking parallels between stories of the past and present be explained? To some extent, certainly, there is a projecting back of contemporary concerns onto recollections of past events. Parents emphasize certain narrative themes in the origin myths because their more recent experiences with the special education system have focused their attention on some aspects of the original diagnosis more than on others. This form of explanation assumes that parents "read back" from present to past, and perceive historical events in their lives in terms of insights and understandings they have acquired more recently.

Although this explanation addresses one aspect of the process through which historical accounts are often constructed, it leaves other questions unanswered. If parents were somehow able to avoid the CSE process entirely, or if their experiences with the CSE were completely positive and harmonious, should we assume that they would not tell the sort of origin stories discussed in this essay? That is, if there were nothing to "read back," would their accounts of the past be dramatically different? Further, should we assume that the origin myths change significantly as the children grow from infancy through adolescence and into adulthood? If present experiences provide a lens for viewing the past, then stories about the past should vary considerably with changes in the circumstances of the family over the years.

My study was not designed to address these questions. Undoubtedly myths do constantly evolve and change, but it is my impression that the essential themes of the origin stories do not vary fundamentally with changes in the circumstances of their narrators. Indeed, it was the similarities of these stories as told by so many different parents in different circumstances that first captured my attention. 
A somewhat different explanation for the thematic parallels between the narratives of past and present involves a process of "reading forward" rather than reading back. According to this form of explanation, the original traumatic encounter with the doctor provides a "template" that structures parents' future experiences and perceptions. The ways in which parents behave in their later dealings with professionals and the ways in which parents interpret these interactions are shaped by the oppositions they first encounter at the time of diagnosis.

This explanation is also persuasive in certain respects, yet it, too, leaves certain questions unanswered. The origin myths are told by many but not all parents. If parents were satisfied with their doctors' handling of the initial diagnosis, should we assume that their later perceptions of educational professionals must also be positive? My data suggest that the contrary is true: regardless of the nature of the initial diagnosis, parents tend to describe their experiences with the special education system in broadly similar terms. These similarities cannot be explained simply in terms of a common experiential "template" that dates back to the time of diagnosis.

Thus, I would hope to suggest an important relationship between narratives of past and present without implying a linkage so tight that either becomes a sine qua non for the other. Processes of "reading back" and "reading forward" certainly occur, but neither interpretive approach fully explains the textual relationships we have explored. A third form of explanation should also be considered, one that emphasizes the affirmative, creative power of myth. Implicit in the retelling of these stories is that, by doing so, the triumphant ending will be achieved again. The myths establish a series of implied comparisons between the past event and the current situation. The internal logic of the myth implicitly compares $A$ in the past to $A_{1}$ in the present, $B$ to $B_{1}, C$ to $C_{1}$, and so forth, thus suggesting that $X$ (the child's triumph over the professional's negative prognosis) will be comparable to $X_{1}$ (the child's triumph over the limited expectations and programming of the professional educators). The retelling of the myth is not only a justification for parents to hold firm in their position on educational issues but a way to make things happen again as they happened before. This is, at least in part, what Eliade ([1949] 1959:74) means when he writes that myth abolishes time and reactualizes the cosmic order as it is figured in the mythic statement. This is the power of the myth, the reason it is told and retold with such intensity. The very act of retelling is a way to ensure that archetypal values and outcomes in the myth will triumph over pain, opposition, and disorder. Some forms of prophesy are self-fulfilling.

Myth-making, in this sense of the term, offers rewards that 
differ from the benefits of law discussed in the preceding section. For a few parents, the law supplies a guarantee that right order-as figured in the origin myth-will once again prevail. The system within which parents and professionals meet and bargain for the child's future is a creature of the law and is pervaded by its norms and procedures. The child's rights within this system could thus serve as the mechanism to "reactualize" the triumph over the professionals that is depicted in the origin stories. Educational rights could help to resolve other oppositions as well: the incongruity of bargaining for material resources by citing personal and emotional needs, for example, or the tension between idiosyncratic decisionmaking practices developed by educators in each school district and the standardized practices required by the act. For some parents, we have said, the law plays such a role. Through the intervention of professional advocates, the wishes and concerns of the parents are converted into a currency of rights that can be traded for resources controlled by the school district. The advocates can also see to it that everyday decisionmaking routines of educators yield to the more regularized, legally reviewable procedures mandated by the IDEA. In this sense, legal intervention can "actualize" the victorious outcomes prefigured in the origin stories.

Yet parents are reluctant to invoke the law-for reasons we have already discussed-and CSE members' comments on the involvement of lawyers in the special education process should, in any case, caution us against concluding that a legal victory for the parents could make their world whole again. For the professional educators, attorney involvement is divisive and estranges the professionals from the parents. It chills relationships rather than reconciling adversaries and creates opposition where none had, in their view, existed before. Invocation of the law may guarantee the kind of triumphant outcome that is the subject matter of the origin myths parents like to retell, but it may also represent no more than a temporary strategic victory in a local skirmish. The potential benefits of law are very great, according to the testimony of parents who have chosen to invoke its protections. But what law cannot do is restore the world that was shattered into oppositional categories at the moment their child was first diagnosed. Perhaps that world can never be recovered; perhaps the experience of its loss is an inevitable part of all human existence. Over time and with experience, the parents of children with disabilities come to understand that the work of law is to confront adversity in a divided world while the work of myth is to transcend it. 


\section{References}

Abrams, Kathryn (1991) "Hearing the Call of Stories," 79 California Law Rev. 971.

Austin, Norman (1990) Meaning and Being in Myth. University Park: Pennsylvania State Univ. Press.

Bell, Derrick (1987) And We Are Not Saved. New York: Basic Books.

Bruner, Jerome (1990) Acts of Meaning. Cambridge, MA: Harvard Univ. Press.

Clifford, James (1988a) The Predicament of Culture: Twentieth-Century Ethnography, Literature, and Art. Cambridge, MA: Harvard Univ. Press.

- (1988b) "Identity in Mashpee," in The Predicament of Culture: Twentieth Century Ethnography, Literature, and Art. Cambridge, MA: Harvard Univ. Press.

Conley, John M., \& William M. O'Barr (1990) Rules versus Relationships: The Ethnography of Legal Discourse. Chicago: Univ. of Chicago Press.

Cunningham, Clark D. (1989) "A Tale of Two Clients: Thinking about Law as Language," 87 Michigan Law Rev. 2459.

Davis, Peggy C. (1989) "Law as Microaggression," 98 Yale Law J. 1559.

Delgado, Richard (1989) "Storytelling for Oppositionists and Others: A Plea for Narrative," 87 Michigan Law Rev. 2411.

Eliade, Mircea ([1949] 1959) Cosmos and History: The Myth of the Eternal Return, trans. W. R. Trask. New York: Harper \& Bros.

- (1963) Myth and Reality, trans. W. R. Trask. New York: Harper \& Row.

Eliot, T. S. (1952) "Little Gidding," in The Complete Poems and Plays, 1909. 1950. New York: Harcourt, Brace \& Co.

Engel, David M. (1984) "The Oven Bird's Song: Insiders, Outsiders, and Personal Injuries in an American Community," 18 Law E' Society Rev. 551.

- (1991) "Law, Culture, and Children with Disabilities: Educational Rights and the Construction of Difference," 1991 Duke Law J. 166.

Estrich, Susan (1986) "Rape," 95 Yale Law J. 1087.

Greenhouse, Carol J. (1986) Praying for Justice: Faith, Order and Community in an American Town. Ithaca, NY: Cornell Univ. Press.

Greenhouse, Carol J., Barbara Yngvesson, \& David M. Engel (forthcoming 1994) Law and Community in Three American Towns. Ithaca, NY: Cornell Univ. Press.

Lincoln, Bruce (1989) Discourse and the Construction of Society: Comparative Studies of Myth, Ritual, and Classification. New York: Oxford Univ. Press.

Marcus, George E., \& Michael M. J. Fischer (1986) Anthropology as Cultural Critique: An Experimental Moment in the Human Sciences. Chicago: Univ. of Chicago Press.

Merry, Sally Engle (1990) Getting Justice and Getting Even: Legal Consciousness among Working-Class Americans. Chicago: Univ. of Chicago Press.

Moore, Sally Falk (1977) "Individual Interests and Organizational Structures: Dispute Settlement as 'Events of Articulation,' " in I. Hamnett, ed., Social Anthropology and Law. New York: Academic Press.

O'Flaherty, Wendy Doniger (1988) Other Peoples' Myths: The Cave of Echoes. New York: Macmillan.

Perin, Constance (1988) Belonging in America: Reading between the Lines. Madison: Univ. of Wisconsin Press.

Sacks, Oliver (1987) The Man Who Mistook His Wife for a Hat and Other Clinical Tales. New York: Harper \& Row.

Sarat, Austin, \& William L. F. Felstiner (1988) "Law and Social Relations: Vocabularies of Motive in Lawyer/Client Interaction," 22 Law $\mathcal{E}^{\prime}$ Society Rev. 737.

PACER Center (1991-92) SEPT/TA Memo, Vol. 4, No. 1. Minneapolis: Supported Employment Parent Training Technical Assistance Project, PACER Center. 
Sherwin, Richard K. (1988) "A Matter of Voice and Plot: Belief and Suspicion in Legal Storytelling," 87 Michigan Law Rev. 543.

Shostak, Marjorie (1981) Nisa: The Life and Words of a!Kung Woman. New York: Vintage Books.

Singer, Isaac Bashevis (1976) "Naftali the Storyteller and His Horse, Sus," in Naftali the Storyteller and His Horse, Sus, and Other Stories. New York: Farrar, Straus \& Giroux.

Stein, Gertrude (1926) Composition as Explanation. London: Leonard \& Virginia Woolf at the Hogarth Press.

Updike, John (1989) Self-Consciousness: Memoirs. New York: Fawcett Crest.

White, James Boyd (1984) When Words Lose Their Meaning: Constitutions and Reconstitutions of Language, Character, and Community. Chicago: Univ. of Chicago Press.

_ (1985) Heracles' Bow: Essays on the Rhetoric and Poetics of the Law. Madison: Univ. of Wisconsin Press.

- (1990) Justice as Translation: An Essay in Cultural and Legal Criticism. Chicago: Univ. of Chicago Press.

Williams, Patricia (1989) "The Obliging Shell: An Informal Essay on Formal Equal Opportunity," 87 Michigan Law Rev. 2128.

Wittgenstein, Ludwig. (1968) Philosophical Investigations, trans. G. E. M. Anscombe. Oxford: Basil Blackwell.

Yngvesson, Barbara (1988) "Making Law at the Doorway: The Clerk, the Court, and the Construction of Community in a New England Town," 22 Law E' Society Rev. 409.

\section{Case}

Board of Education of the Hendrick Hudson Central School District v. Rowley, 458 U.S. 176 (1982).

\section{Statutes}

Education for All Handicapped Children Act of 1975, Pub. L. No.94-142, 89 Stat. 773 (1975).

Education of the Handicapped Act Amendments of 1990, Pub. L. No.101476, 104 Stat. 1103 (1990).

Individuals with Disabilities Education Act, 20 U.S.C. $\S \S 1400-1485$ (1988 \& Suppl. 1991).

New York Education Law sec. 4402(1)(b)(1) (McKinney 1981 \& Supp. 1992).

New York Education Law sec. 4402(1)(b)(1) (McKinney 1981 \& Supp. 1993). 